\title{
Silica Froth: An Indicator of Thatch Artchitecture
}

David H. Jurney

Unknown

Velicia Bergstrom

Follow this and additional works at: https://scholarworks.sfasu.edu/ita

Part of the American Material Culture Commons, Archaeological Anthropology Commons, Environmental Studies Commons, Other American Studies Commons, Other Arts and Humanities Commons, Other History of Art, Architecture, and Archaeology Commons, and the United States History Commons

Tell us how this article helped you.

This Article is brought to you for free and open access by the Center for Regional Heritage Research at SFA ScholarWorks. It has been accepted for inclusion in Index of Texas Archaeology: Open Access Gray Literature from the Lone Star State by an authorized editor of SFA ScholarWorks. For more information, please contact cdsscholarworks@sfasu.edu. 


\section{Silica Froth: An Indicator of Thatch Artchitecture \\ Creative Commons License \\ (c) (1) \& 8}

This work is licensed under a Creative Commons Attribution-NonCommercial 4.0 International License 


\title{
SILICA FROTH: AN INDICATOR OF THATCH ARCHITECTURE ${ }^{1}$
}

\author{
David H. Jurney and Velicia Bergstrom
}

\begin{abstract}
Archaeological reports of silica froth are noted from Kansas to Texas, and are usually interpreted as evidence of burned grass- or cane-thatched buildings. However, many archaeological excavations in the Caddoan region fail to mention this material. Does this reflect idiosyncratic factors in the formation of silica froth, lack of expertise on the part of excavators/analysts, or differential recovery techniques? Archaeological and experimental data indicate that Caddoan houses frequently left silica froth as a residue when they burned. The implications are that archaeologists may be missing this key architectural item and that silica froth may be used to infer the presence of a house in the absence of traditional features such as post molds.
\end{abstract}

\section{INTRODUCTION}

This paper is a result of a literature search, Internet search, and personal query of archaeologists in the Southeastern and Midcontinental United States relating to Caddoan and thatch architecture. The authors observed a fused silica material from Caddoan sites on the National Forests and Grasslands in Texas, and found this material at the site of the burned experimental Caddo house at the Caddoan Mounds State Historic Site (George C. Davis site) in Texas (Figure 1). Since this material is not generally recognized or reported, we decided that it is necessary to define the known occurrence of this material and identify the circumstances that lead to its production.

\section{ARCHAEOLOGICAL OCCURRENCES}

The earliest known reference to fused silica is by Pliny the Elder, describing Iron Age furnaces in Europe (Irv Rovner, North Carolina State University, personal communication 2000). Here, wheat straw and chaff were used to increase the firing temperature of foundries, leaving the fused silica as a residue.

The first known archaeological report describing fused silica as "greenish-gray bubbly particles" was from the Longest Site, an early historic Wichita village along the Red River in Texas and Oklahoma (Bell et al. 1967:1). Ed Jelks reports that this material was puzzling to them, and they eventually concluded that it was produced by burning grass thatch on the buildings. Tyler Bastian examined the remains of a recently burned barn in Oklahoma while they were working on the report, and found this residue where the hay had burned (Ed Jelks, personal communication 1999). Dan Rogers found this 
material scattered over the Spiro site in eastern Oklahoma in 1979, and concentrated near the locations of former buildings. Rogers states "concentrations of this material with house remains can be used to suggest that the structure was burned" (Rogers 1980:175). The senior author participated in this project, and became familiar with the recognition of fused silica. Despite years of field work in north central Texas, Jurney did not observe this material again until he joined the U.S. Forest Service, and worked on Caddoan hamlets in the Davy Crockett and Sabine National Forests.

Dee Ann Story reports that the only fused silica of which she is aware comes from the George C. Davis site (Story 1972, 1981), Mound B, Feature 111. This consisted of a relatively dense concentration of fused silica, interpreted to be from a burned building. There was none of this material recovered from the Deshazo site (Story 1982, 1995) in Nacogdoches County, Texas. She feels that the lack of this material at many Caddoan sites may be due to the fact that relatively few houses burned; many apparently rotted in place.

The Hargrove Lake site (41HO150), a Caddoan hamlet on the Davy Crockett National Forest in Houston County, Texas, yielded several pieces of fused silica in areas that were interpreted as houses (Jurney 1999). Burned mud dauber nests, concentrations of large pottery sherds from reconstructable vessels, and fire-cracked rocks from hearths were additional data supporting the association with houses. Silica froth has also been recovered from two sites (41SY43, the Old Timers site, and 41SY219, the Tenaha Bayou site), both Caddoan hamlets, on the Sabine National Forest, in Shelby County, Texas (Ippolito et al. 1999).

Other accounts of fused silica have not been confirmed in the literature, but have been reported by other researchers. Richard Krause apparently recovered fused silica from an Upper Republican site at the Forks of the Solomon River in Kansas during the 1960s. Lynne Sullivan (McClung Museum, University of Tennessee) reports that no evidence of fused silica has been recovered from Dallas phase sites in Tennessee. There are frequent concentrations of bumed cane (matting, partitions, carpets, etc.) found in Dallas phase houses, however. Sullivan remembers fused silica "clinkers" from Cahokia, but this report has not been verified. They were interpreted as residue from the burning of coal. David Jeane (Arkansas Archeological Survey, Magnolia) reports that he and Clarence Webb found this material at the Montgomery site in Spring Hill, Louisiana, and that it is found at the Martin site in southwestern Arkansas. Mark Harrington and James Ford found this material at the Menard site on the Arkansas River in eastern Arkansas. Cathy Cande has recovered it from the Goldsmith site near Little Rock. Pete Gregory reports that big chunks of this material were found at the Belcher site in northwestern Louisiana, but they were not reported since no one knew what they were. Tom Eubanks reports that this material is frequently found on the island of Tobago, where they are related to sugar cane fluxes in furnaces. Louis Vogele reports that Joe Caldwell found clinkers in the Norman Mound, in eastern Oklahoma. Gayle Fritz reports that she often finds this residue in flotation sample for plant identification. She lists the occurrence in her reports, but it is not known if the archaeologists are aware of the significance of this material. 


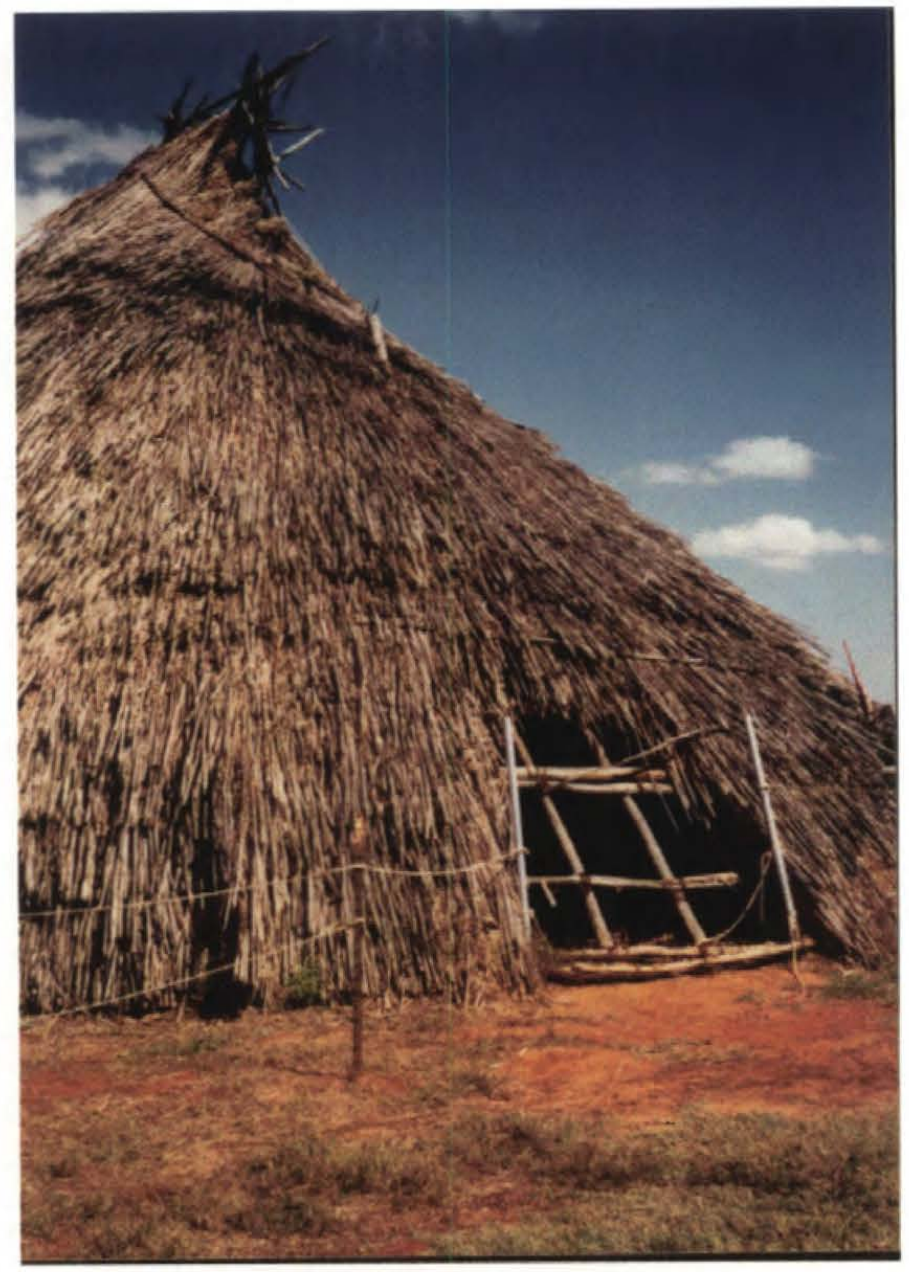

Figure 1. Reconstructed Caddoan House at the George C. Davis Site (Caddoan Mounds State Historic Site). 


\section{NATURE AND CAUSE OF SILICA FROTH}

Ed Jelks reports that silica is the essential agent in clay leading to "lithification." It combines with any of several substances that can act as fluxes, including soda, potash, lime, and magnesia. They combine with the silica in the same chemical reaction by which glass is made. The fused silica from grass thatch apparently comes from the opal phytoliths (pure quartz) in grasses, possibly combining in a flux with potash.

The Caddoan House at the George C. Davis site was built as an archaeological research project, designed by Dee Ann Story. The house, thatched with giant cane (Arundinaria sp.), was duplicated from Domicile 10 at the Davis site and measured $7.6 \mathrm{~m}$ $(25 \mathrm{ft})$ in diameter and $9.1 \mathrm{~m} \mathrm{(30} \mathrm{ft)} \mathrm{in} \mathrm{height,} \mathrm{with} \mathrm{four} \mathrm{interior} \mathrm{living/storage} \mathrm{levels}$ (Cheatham 1992). Within a year of its construction, a tornado damaged the building, and in 1990 vandals removed the storage levels, further weakening the building. In 1995, the house was burned as a continuation of the experiment (Figure 2). Unfortunately, a thermocouple was not placed in the building to record temperatures that affect features and contents placed in the building. The authors of this paper returned to the burned house site in 1997 during Passport in Time Investigations of the Hargrove Lake Site, and found fragments of fused silica (Figure 3 ) in the area where the burning cane thatch fell to the ground as the building collapsed. The fused silica was similar, but not identical, to that recovered from the Hargrove Lake Site. Also, the silica froth fell outside the north wall of the house. Subsequent visits and collection in 1999 indicated that the silica froth has been fragmented by mowing and foot traffic around the house replica's former location.

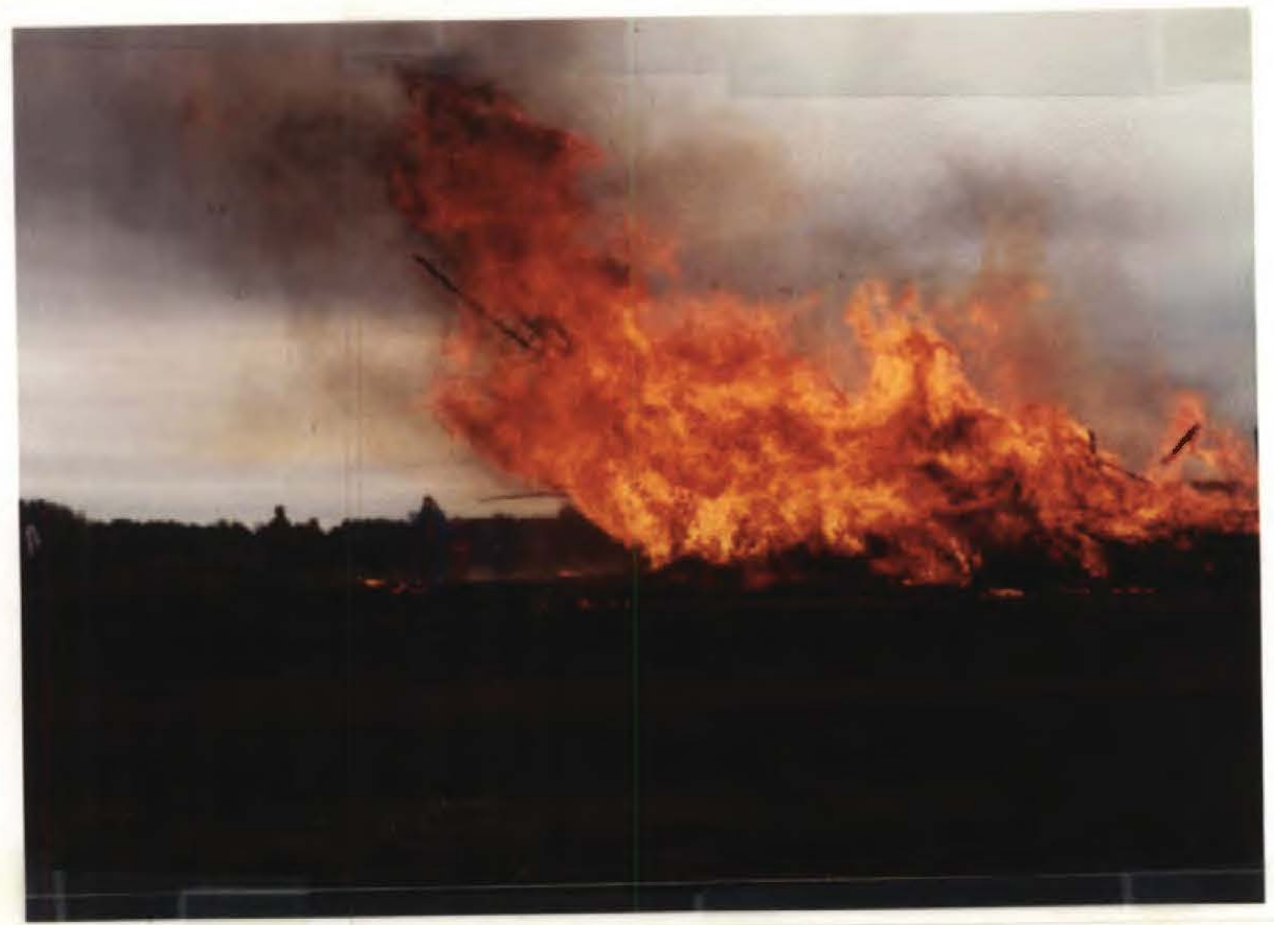

Figure 2. Burning of the Caddoan house at the George C. Davis site. The fused silica is forming in the collapsing thatch in the center of the fire. 

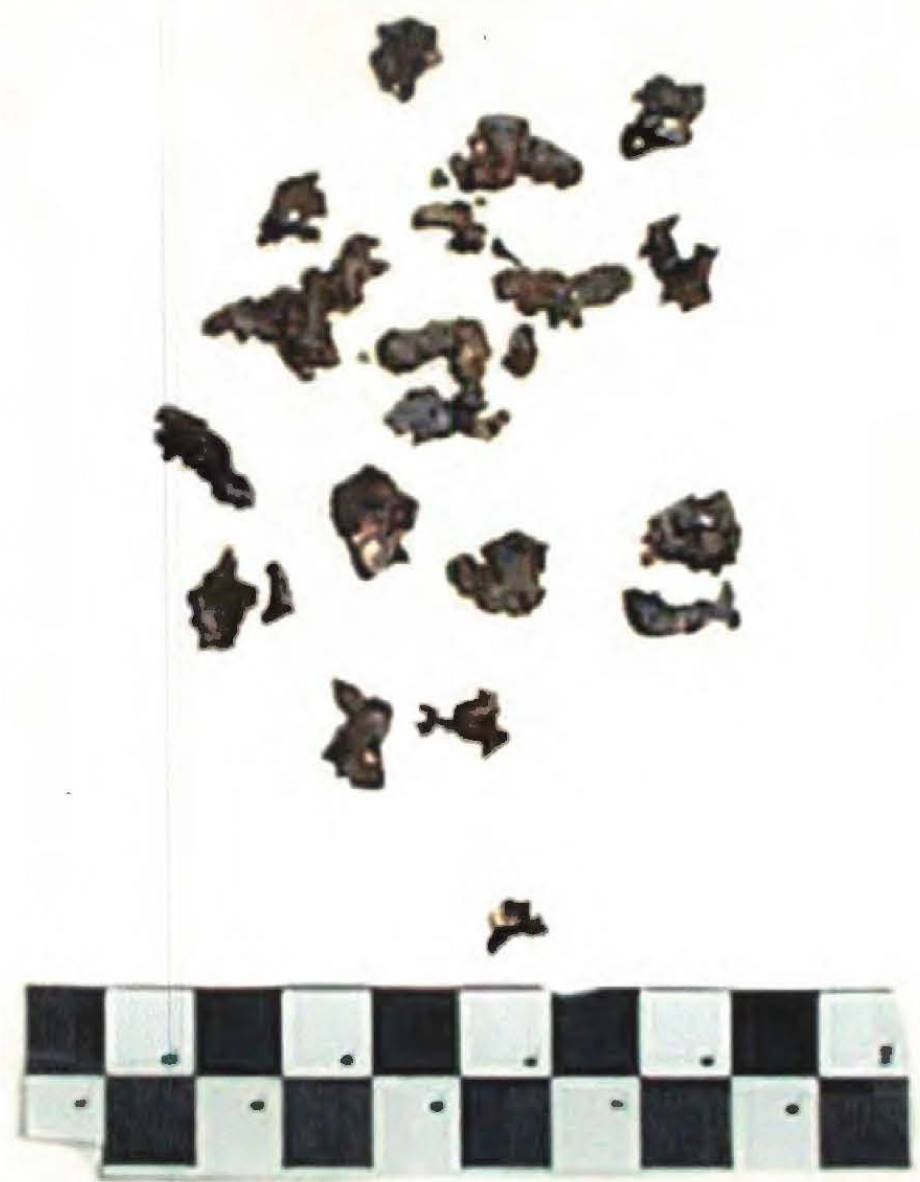

Figure 3. Fused silica collected from the buming of the replica house at the George $\mathrm{C}$. Davis site.

\section{RECOGNITION PROBLEMS}

In conversations with Dee Ann Story, she identified several factors that may contribute to the lack of recognition of fused silica on Caddoan archaeological sites. First is the problem of recognition. Few archaeologists have seen this material, and much of it may have been squashed through screens. Second, Dee Ann feels that relatively few Caddo houses were burned. In conversations with Irv Rovner, another factor was identified. The point at which opal phytoliths melt is somewhere between $600-1000^{\circ}$ Fahrenheit. Depending on ventilation and wind, the grass or cane thatch may not reach a suitable temperature to fuse the silica contained as opal phytoliths, or the material may be consumed at higher degrees. Also if there is substantial rebuilding or subsequent disturbance of the silica froth, it may consist of smaller fragments or deteriorate totally.

Recent investigation of the Oldtimers site (41SY43), at the location of a supposed house, failed to yield evidence of post molds. There was evidence of a central hearth, based on fire-cracked rock fragments, burned silt, fired mud dauber nests, and ashes. Also, several fragments of fused silica froth were recovered. One extremely well preserved fragment is shown in Figure 4. It appears that post molds do not preserve their soil contrast in deep sandy soils. Therefore, silica froth may be one of several indicators of former architecture. 

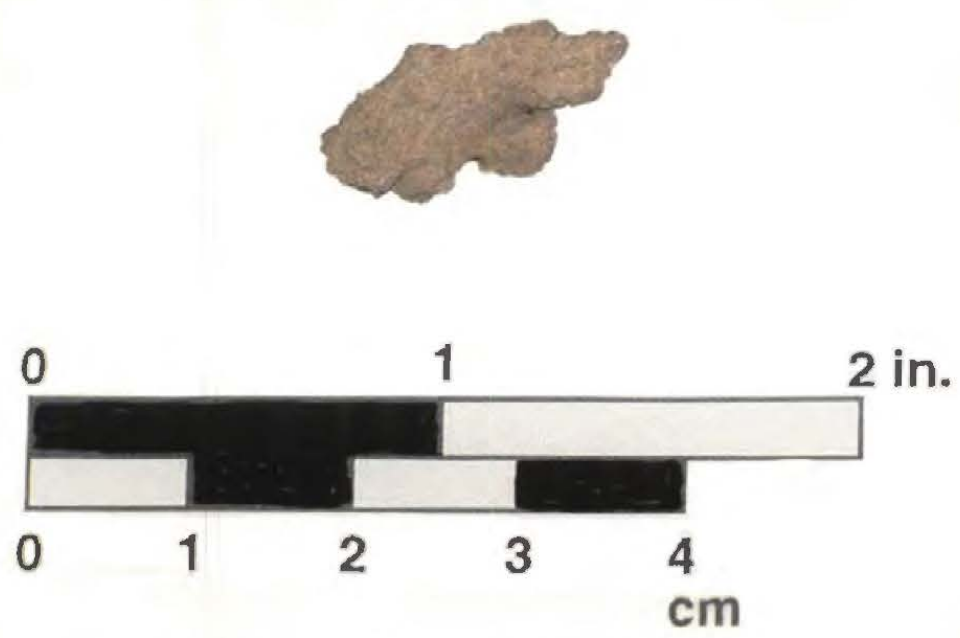

Figure 4. Example of fused silica froth from the Oldtimers site (41SY43).

We hope that this paper will generate interest in this material, and that researchers in the Caddoan area will design their recovery techniques to deal with this phenomenon. We need to reconstruct the above-ground architecture on the basis of the remains we recover. Any replicas scheduled for reconstruction should be considered as candidates for experimental burning. Use a thermocouple.

\section{END NOTE}

1. Paper presented at the $42^{\text {nd }}$ Caddo Conference, Natchitoches, Louisiana, February 2526,2000

\section{REFERENCES CITED}

Bell, Robert E., Edward B. Jelks, and W. W. Newcomb

1967 A Pilot Study of Wichita Indian Archaeology and Ethnohistory. Final report to the National Science Foundation, Washington, D.C.

Cheatham, Scooter

1992 The Caddo House Reconstruction. Bulletin of Primitive Technology 1 (3):22-24.

Ippolito, John, David H. Jurney, Velicia Bergstrom, Elaine Sherman, Wally Kingsborough, and Phyllis Wolf

1999 Report on FY1998 Archaeological Investigations on the National Forests and Grasslands in Texas. Report submitted to the Texas Historical Commission by the U.S. Forest Service, Lufkin, Texas. 
Jurney, David $\mathrm{H}$.

1999 Passport In Time Archaeological Investigations at the Hargrove Lake Site (41HO150), Houston County, Texas. Report submitted to the Texas Historical Commission by the U.S. Forest Service, Lufkin.

Rogers, J. Daniel

1980 Spiro Archaeology: 1979 Excavations. Studies in Oklahoma's Past 6. Oklahoma Archeological Survey, Norman.

Story, Dee Ann (editor)

1972 A Preliminary Report on the 1968, 1969, and 1970 Excavations at the George C Davis Site, Cherokee County, Texas. Report submitted to the National Science Foundation, Grants GS-2573 and 3200; and the Office of the State (Texas) Archaeologist. Ms on file, the Texas Archeological Research Laboratory, The University of Texas at Austin.

1981 Archeological Investigations at the George C. Davis Site, Cherokee County, Texas: Summers of 1979 and 1980. Occasional Papers 1. Texas Archeological Research Laboratory, The University of Texas at Austin.

1982 The Deshazo Site, Nacogdoches County, Texas, Volume 1. Texas Antiquities Permit Series No. 7. Texas Antiquities Committee, Austin.

1995 The Deshazo Site, Nacogdoches County, Texas, Volume 2: Artifacts of Native Manufacture. Studies in Archeology 21. Texas Archeological Research Laboratory, The University of Texas at Austin. 